\title{
Sedimentology and Permeability Distribution of the Ajali Sandstone around Odugbo, North Central Nigeria
}

\author{
Odedede, O. ${ }^{1} \&$ Adaikpoh, E. O. ${ }^{1}$ \\ ${ }^{1}$ Department of Geology, Delta State University, Abraka, Delta State, Nigeria \\ Correspondence: Adaikpoh, E. O., Department of Geology, Delta State University, Abraka, Delta State, Nigeria. \\ Tel: 234-803-727-4021. E-mail: adaikpoh_edwino@yahoo.com
}

Received: May 7, 2013 Accepted: May 24, 2013 Online Published: June 16, 2013

doi:10.5539/jgg.v5n3p1 URL: http://dx.doi.org/10.5539/jgg.v5n3p1

\begin{abstract}
Ajali Sandstone around Odugbo, North Central Nigeria was studied in order to determine its sedimentological characteristics and permeability distribution. The study involves both field mapping, samples collection from different outcrops locations and laboratory analyses. Grain size analysis revealed that the sandstones are composed of medium grained (av. 1.50 ф), poorly sorted (av. 1.60 ф) and sub-angular to sub-rounded grains which indicate deposition close to the source area. Permeability values deduced from an empirical formula are generally low with an average value of $46.76 \mathrm{md}$ indicating that the sandstones have poor flow characteristics. The low permeability is considered to have resulted from weathering and grained dissolution during the formation of hematite cement. Petrographic study shows that the sandstones are composed of mainly quartz (av. 95.08\%), feldspar (av. 2.55\%) and mica plus rock fragments (1.19\%), and suggests texturally mature and mineralogically mature quartz arenite. This study also presents the trend suggestive that sedimentary structures and depth of burial can be considerable factors affecting sandstone permeability.
\end{abstract}

Keywords: permeability distribution, Ajali Sandstone, Nigeria, grain size distribution, reservoir architecture

\section{Introduction}

Sandstones, either consolidated or unconsolidated, are known to be prolific source of groundwater as well as important reservoir rocks in most petroleum provinces. Ajali Sandstone which is the focus of this study, has been studied sedimentologically by several workers who utilized the associated primary and biogenic structures to deduce the provenance, and characterize its depositional environment (Hoque \& Ezepue, 1977; Ladipo, 1986). The Ajali Sandstone is an extensive stratigraphic unit conformably overlying the Lower Coal Measure (Mamu Formation) and underlying the Upper Coal Measure (Nsukka Formation). The environment of deposition of the formation has also been discussed by various authors namely Reyment (1965), Hoque and Ezepue (1977) and Ladipo (1986). This study examines the sedimentology and permeability distribution of the Ajali Sandstone as exposed around Odugbo, North Central Nigeria through detailed field mapping and laboratory analyses of some of the rocks, and inference were made after geostatistical deductions.

\subsection{The Study Area}

The study area lies within longitude $006^{0} 53^{\mathrm{I}} \mathrm{E}$ to $007^{0} 00^{\mathrm{I}} \mathrm{E}$ and latitude $07^{0} 41^{\mathrm{I}} \mathrm{N}$ to $07^{0} 49^{\mathrm{I}} \mathrm{N}$ (Figure 1). The area lies within the Anambra Basin.

The Anambra Basin is an Upper Cretaceous sedimentary basin located in the Southern portion of Nigeria and bounded by the Lower Benue Trough to the East and by the Basement Complex of the southwestern Nigeria. The Basin has been extensively studied by various workers (Akande et al., 2007; Okogbue et al., 2012) for its coal and shale characterization. The paleogeography, sedimentation and tectonics are documented by such works as Murat, 1972; Ladipo, 1988; \& Obi et al., 2001). According to Murat (1972) and Obi et al. (2001), the tectonic evolution of the southern sedimentary basin probably started in Early Cretaceous times with the formation of the Benue-Abakaliki Trough as a failed arm of the rift triple junction associated with the separation of African and South American continents and subsequent opening of the South Atlantic. 


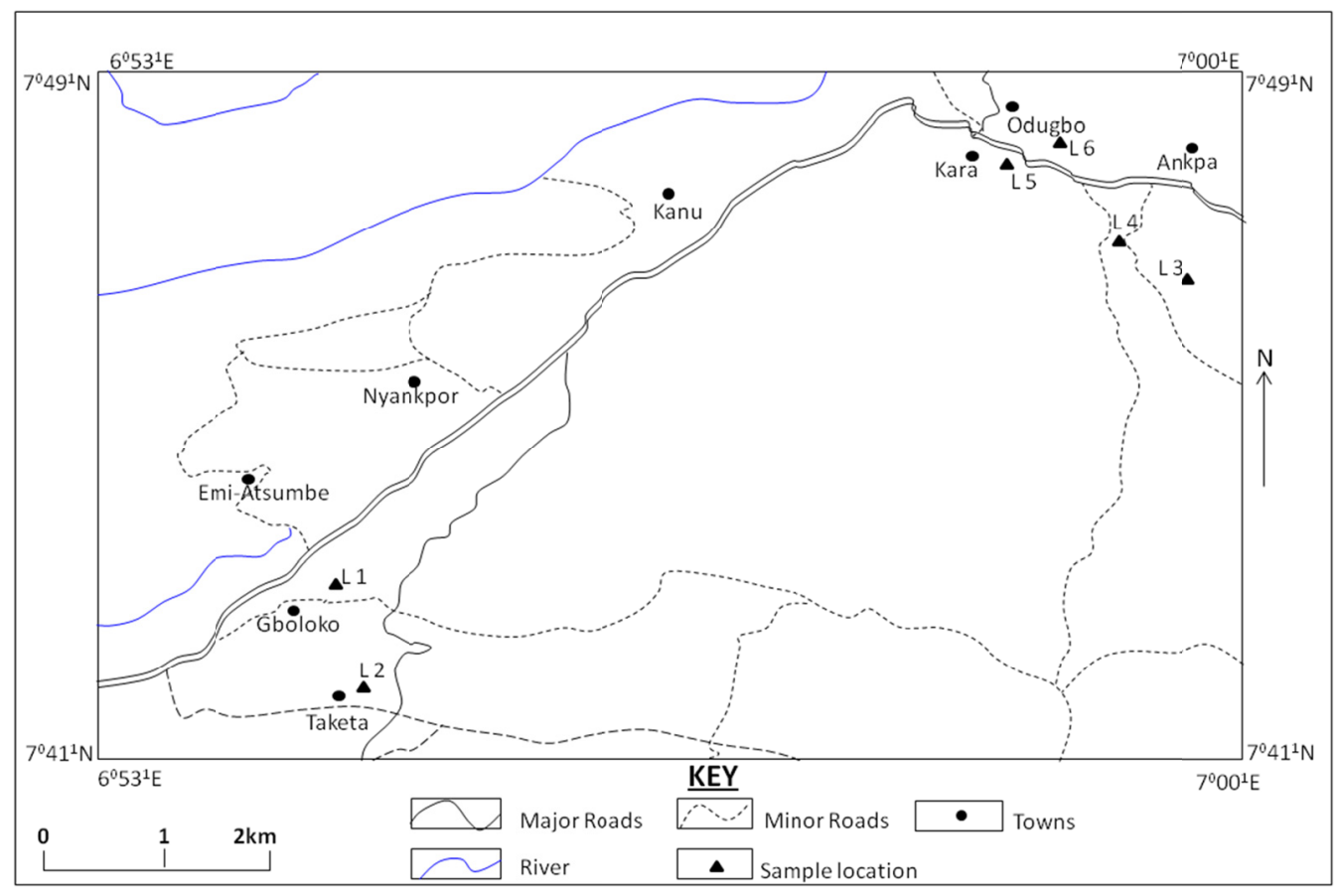

Figure 1 . Accessibility map of the study area

A compressional folding that affected the Lower Benue Trough took place during the Santonian and the main fold structure produced was the northeast to southwest trending Abakaliki anticlinorium which resulted from the inversion of the Abakaliki Trough. The second tectonic episode (renewed rifting) occurring during Post-Santonian time and produced the main Post-Santonian depocentre at the western flank and a smaller Afikpo basin on the southeastern flank. The Santonian uplift resulted in the erosion of over $2000 \mathrm{~m}$ of sediment from the Abakaliki folded bed which was deposited in the Anambra basin. The sedimentary history resulted from the Santonian folding and uplift of the Abakaliki region and dislocation of the depocenter into the Anambra platform and Afikpo region comprising the Nkporo Group, Mamu Formation, Ajali Sandstone, Nsukka Formation, Imo Formation and Ameki Group (Table 1). The Ajali Sandstone is Maastrichtian in age (Murat, 1972) and is composed of unconsolidated medium to coarse grained subangular to subrounded quartz arenite laterally laid in a sheet - like geometry (Ladipo, 1986). Allix (1987) regarded the Ajali Sandstone as fluvially derived but reworked in a marine environment.

Table 1. Regional lithostratigraphic framework for southern Nigeria (Adapted from Murat, 1972 and Hoque, 1977)

\begin{tabular}{|c|c|c|c|c|c|}
\hline Age & & Basin & Lithographic units & Sedim & tary cycles \\
\hline \multirow[t]{2}{*}{ Cenozoic } & Eocene & \multirow{6}{*}{$\begin{array}{l}\text { Anambra } \\
\text { Basin/Afikpo } \\
\text { Sub-basin }\end{array}$} & $\begin{array}{l}\text { Ameki Formation/Nanka } \\
\text { sands }\end{array}$ & \multirow{6}{*}{\multicolumn{2}{|c|}{$\begin{array}{l}\text { Second Sedimentary } \\
\text { Cycle }\end{array}$}} \\
\hline & Paleocene & & Imo Formation & & \\
\hline \multirow{8}{*}{ Upper Cretaceous } & Late Maatrichtian & & Nsukka Formation & & \\
\hline & Mid Maatrichtian & & Ajali Sandstone & & \\
\hline & Early Maatrichtian & & Mamu Formation & & \\
\hline & Late Campanian & & Nkporo Formation & & \\
\hline & Santonian & & Santonian Uncomformity & & \\
\hline & Coniacian & \multirow{4}{*}{ Benue Trough } & Agwu Formation & \multirow{4}{*}{$\begin{array}{l}\text { First } \\
\text { Cycle }\end{array}$} & \multirow{4}{*}{ Sedimentary } \\
\hline & Turonian & & Eze-Aku Group & & \\
\hline & Cenomanian & & Odukpani Group & & \\
\hline Lower Cretaceous & Albian & & Asu River Group & & \\
\hline
\end{tabular}




\section{Method of Study}

\subsection{Field Procedure}

A systematic geologic mapping of the Ajali Sandstone around Odugbo was carried out using a topographic base map on a scale of 1:69000. Bedding characteristics in terms of structure, texture, and lithology were observed and described for all the outcrops encountered.

\subsection{Analytical Procedure}

Grain size distribution in the study area was achieved through mechanical sieving of a total number of ten samples of sandstone collected from surface outcrops. These samples were first sun - dried and disaggregated with hands. The samples were sieved according to the procedure of Friedman (1979) and statistical formulae of Folk and Ward (1957) was used to derive textural parameters. Sieve data were plotted on semi-log sheet to determine the $50^{\text {th }}$ percentile or median diameter $\left(\mathrm{d}_{50}\right)$ and sorting. These were then substituted into the empirical formula $\left(\mathrm{K}=\mathrm{C}_{\mathrm{o}} \mathrm{D}_{\mathrm{m}}^{2} \mathrm{e}^{-1.31} \sigma\right)$ proposed by Krumbrien and Monk, (1942) to estimate permeability of the sandstone. Where $\mathrm{k}=$ permeability (millidarcies), $\mathrm{C}_{\mathrm{o}}=$ an empirical constant $\left(760\right.$ darcies $\left./ \mathrm{mm}^{2}\right), \mathrm{D}_{\mathrm{m}}=$ median diameter $(\mathrm{mm})$, and $\sigma=$ sorting. The assessment of permeability for reservoir unit can be done using empirical formula since the general relationship between permeability and porosity in sandstone remains valid Kriesa et al. (1999).

Thin sections were prepared for six samples for petrographic study. The point - counting method of Ingersoil et al. (1984) adopted by Tijani, et al. (2010) was used for the different mineral grains quantitative compositional analysis while the modal analysis was by counting more than 300 points per thin section according to Dickson (1970).

\section{Results and Discussion}

\subsection{Results}

The geology (Figure 2) of Odugbo area is defined by sedimentary rocks such as sandstone and shale. These rock units show physical sedimentary structures which are commonly cross bedding and lamination.

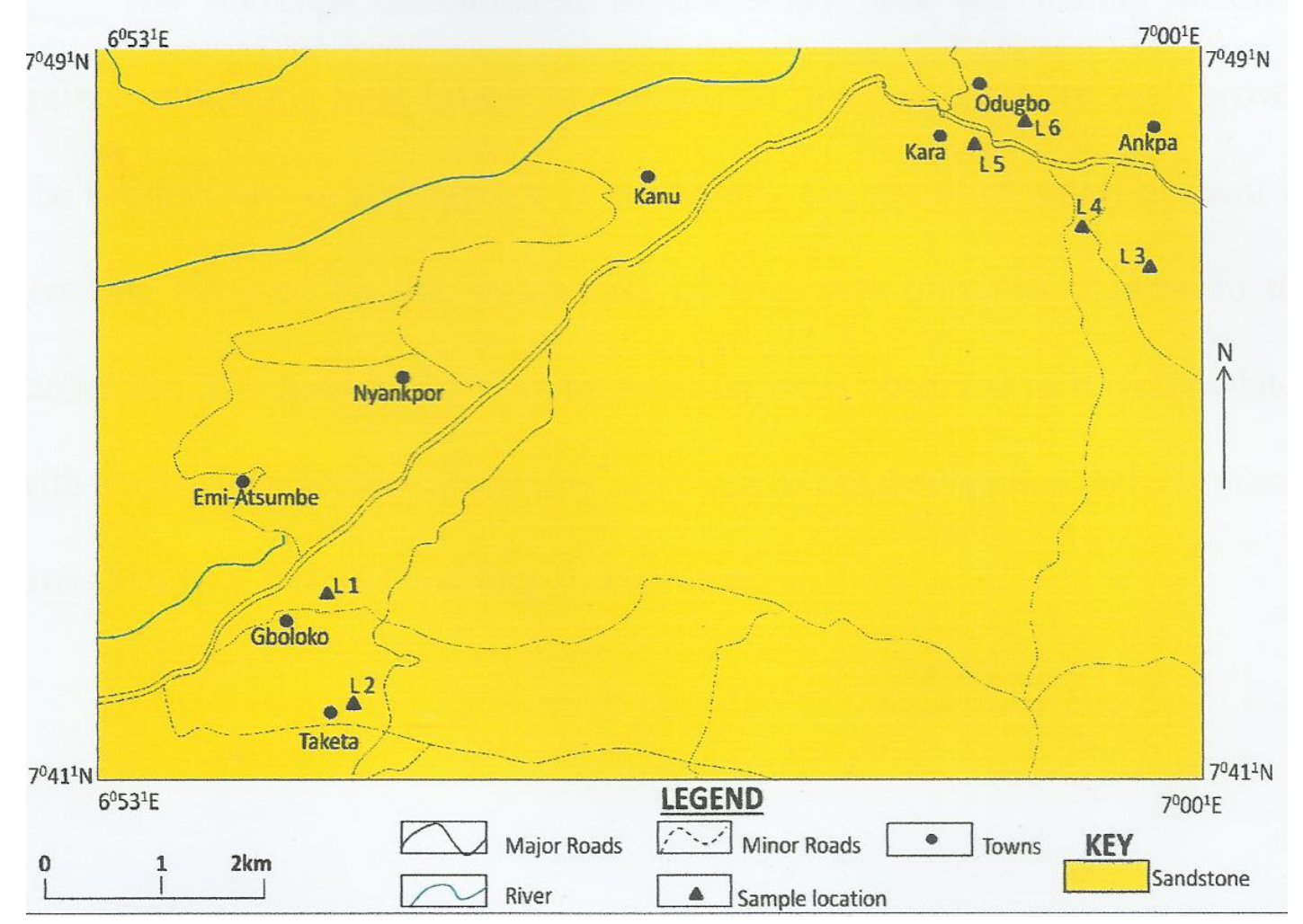

Figure 2. Geological map of the studied area 


\subsubsection{Lithologic Description}

Lithological sections of the Ajali Sandstone exposed along road cut at different locations in Odugbo were described and erected in a stratigraphic section (Figure 3). The basal part of the section is made up of reddish brown, medium grained, moderately sorted sandstone which are cross bedded (Figures 4 and 5) with foresets dipping at low angles $\left(<10^{\circ}\right)$. Contact with the overlying stratum is gradational. Overlying this unit is a laminated grey shale. The lithofacies and sedimentary structures indicate a low energy of deposition. Succeeding this unit is a thickly bedded sandstone (Figure 6) interbedded with shale. An exposure in the upper part of the Ajali Sandstone is seen at $\mathrm{Km} 2$ north of old Odugbo. The lithology is made up of whitish, poorly - moderately sorted medium grained tabular cross bedded sandstone with sets $1.2-3$ metres (Figures 7 and 8 ). The entire coset is 12 metres thick and stoss-side laminae are well preserved. Physical sedimentary structures indicate fluvial environment of deposition (Tucker, 1996; Odedede, 2011)

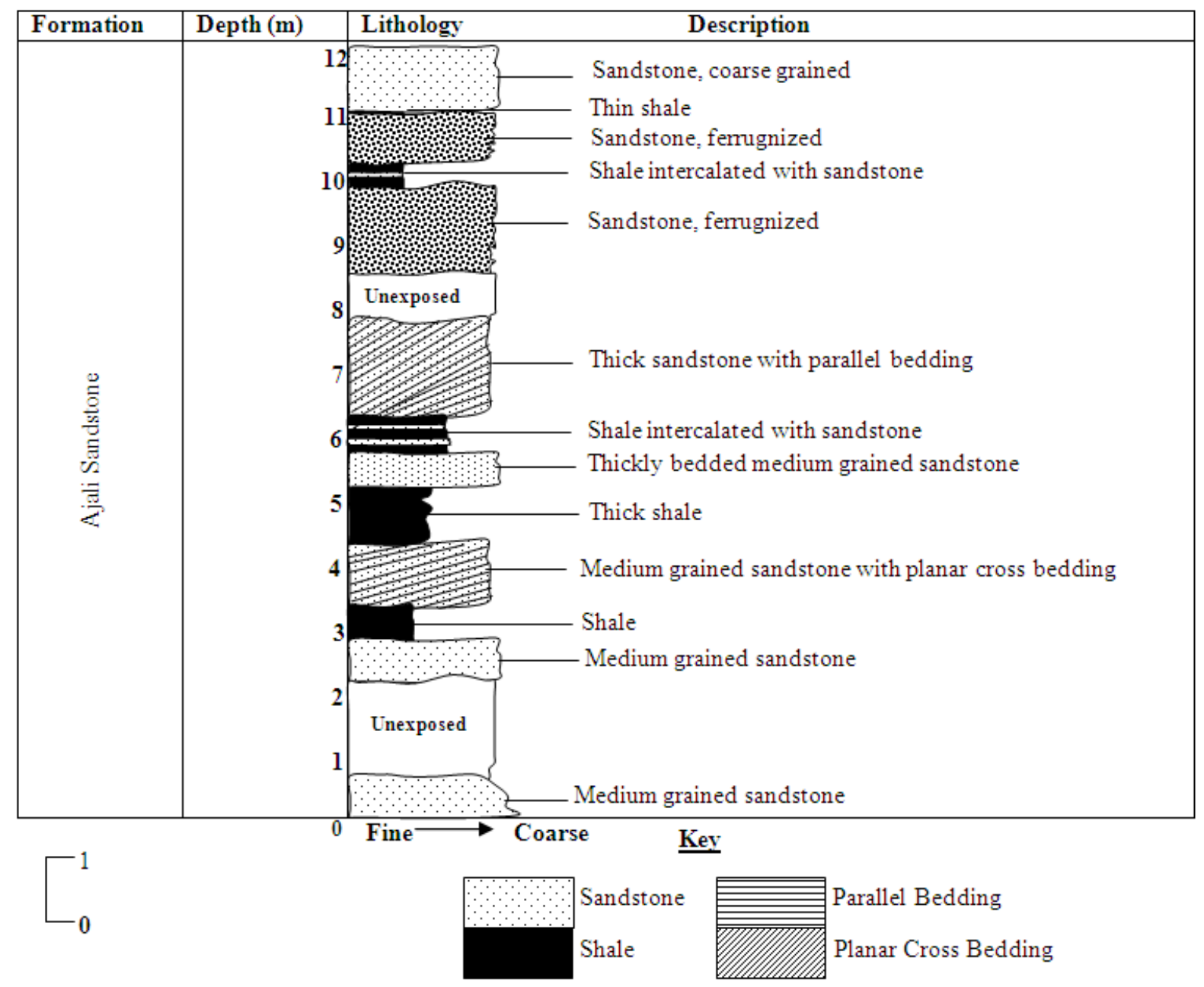

Figure 3. Detailed stratigraphic log of the Ajali sandstone around Odugbo 


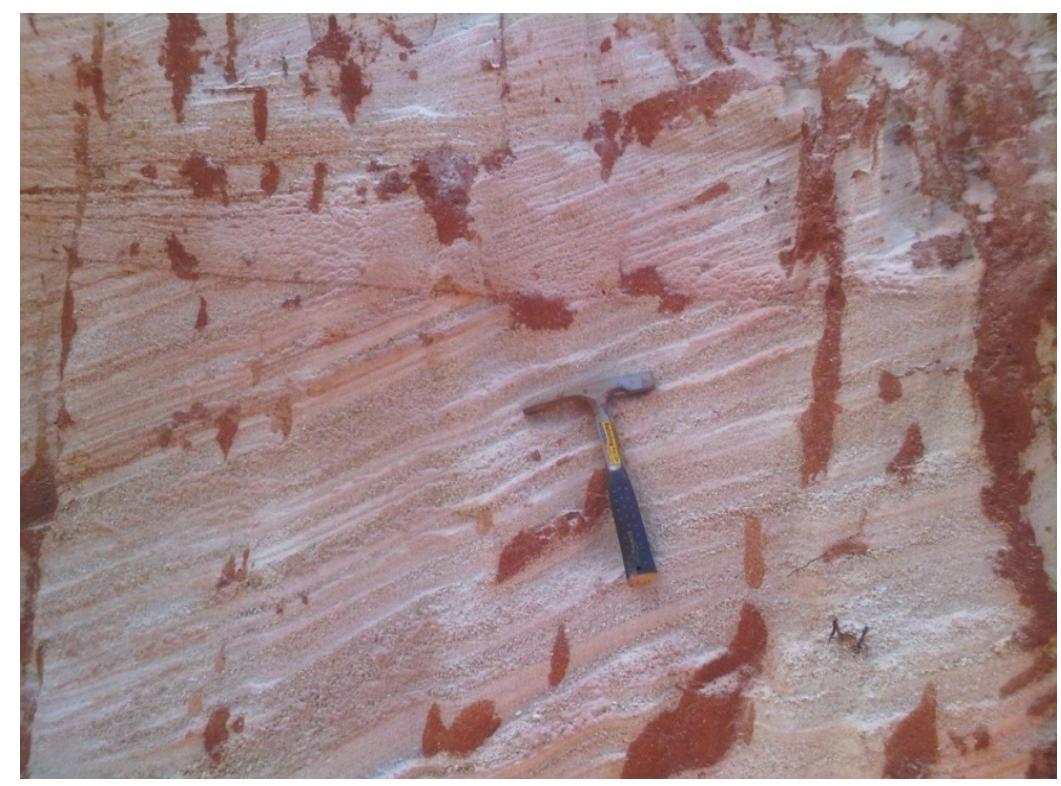

Figure 4. Planar cross bedded sandstone of the Ajali Sandstone around Odugbo

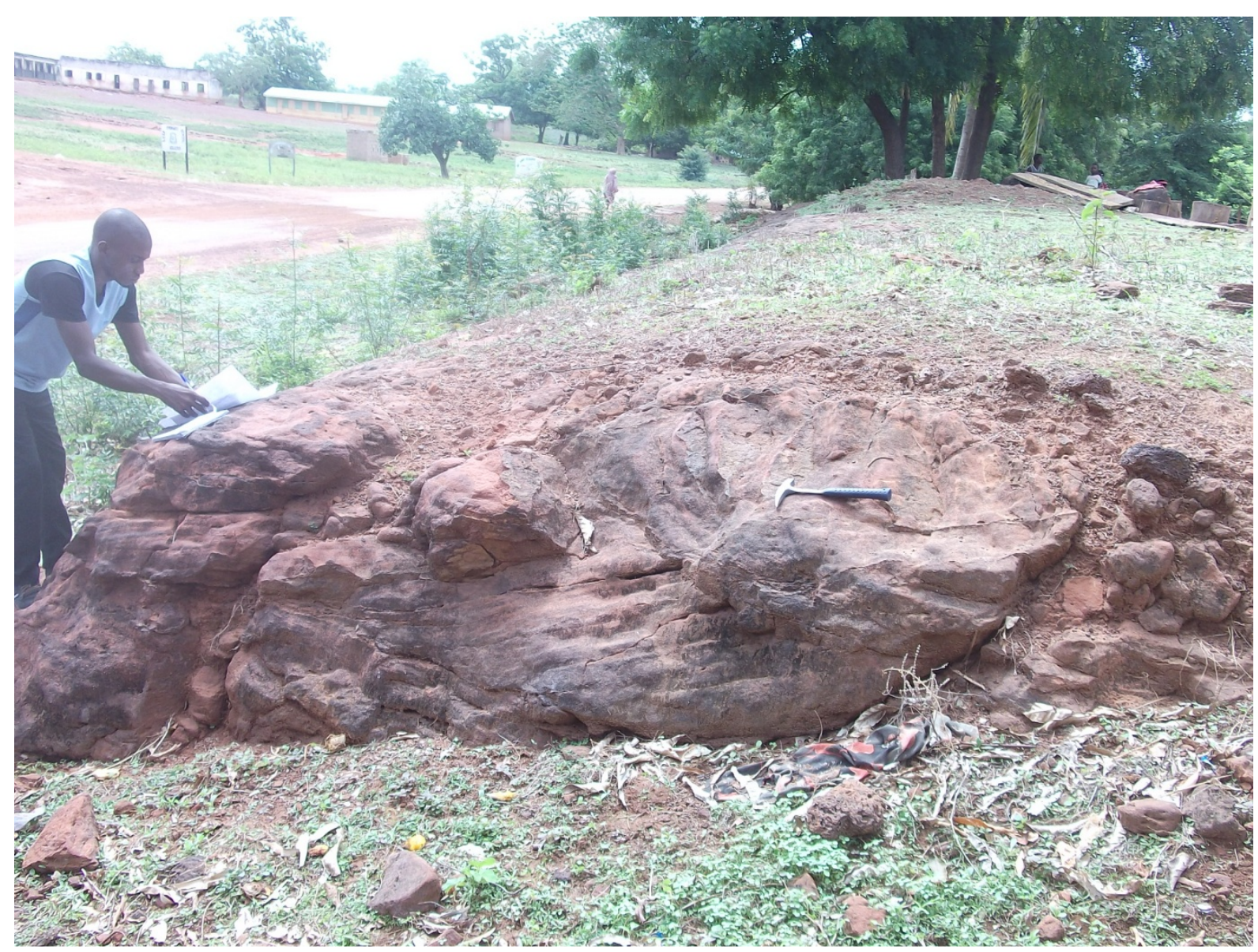

Figure 5. Reddish cross bedded sandstone of the Ajali Sandstone around Odugbo 


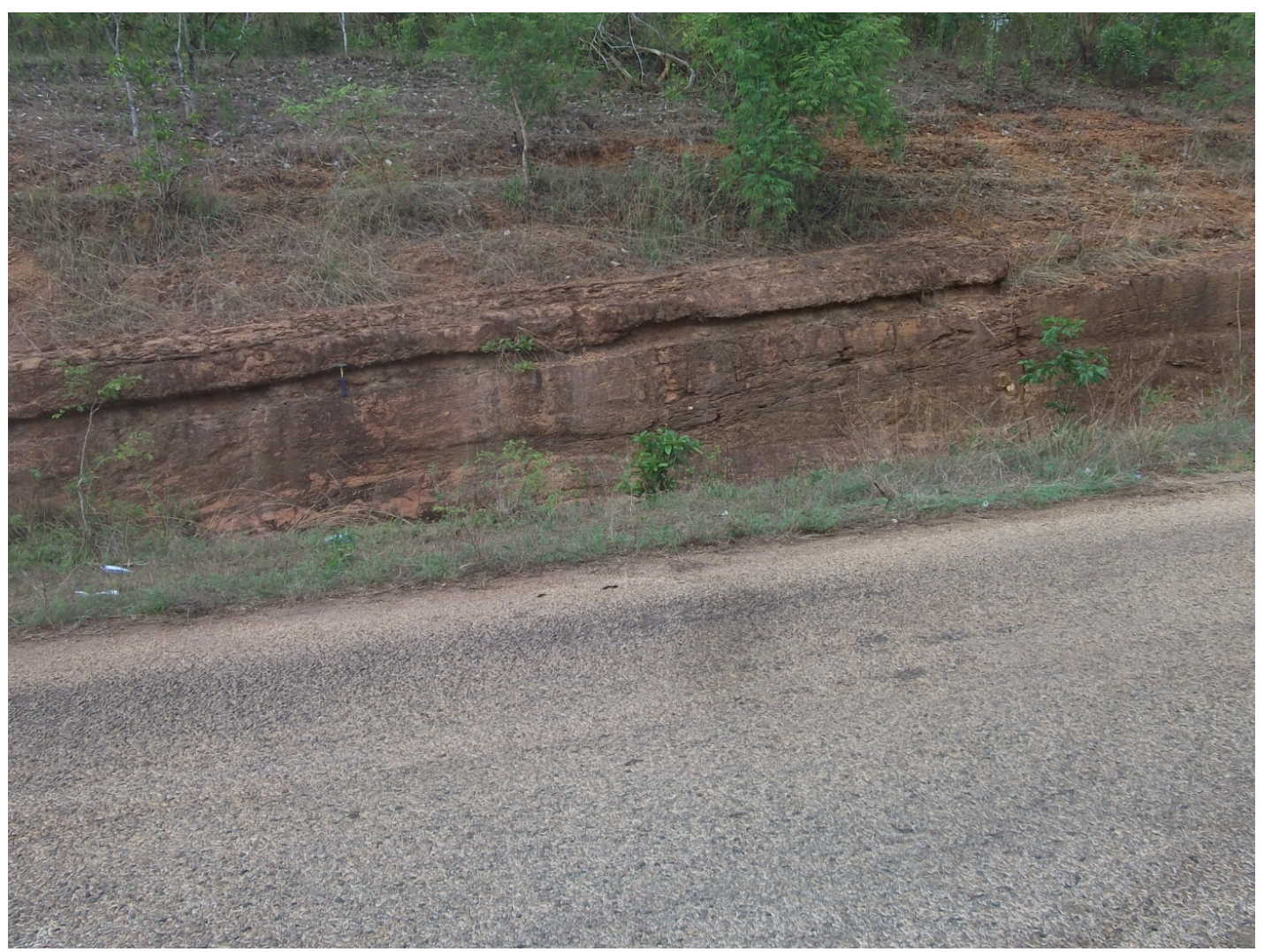

Figure 6. Thickly bedded sandstone of the Ajali Sandstone around Old Odugbo

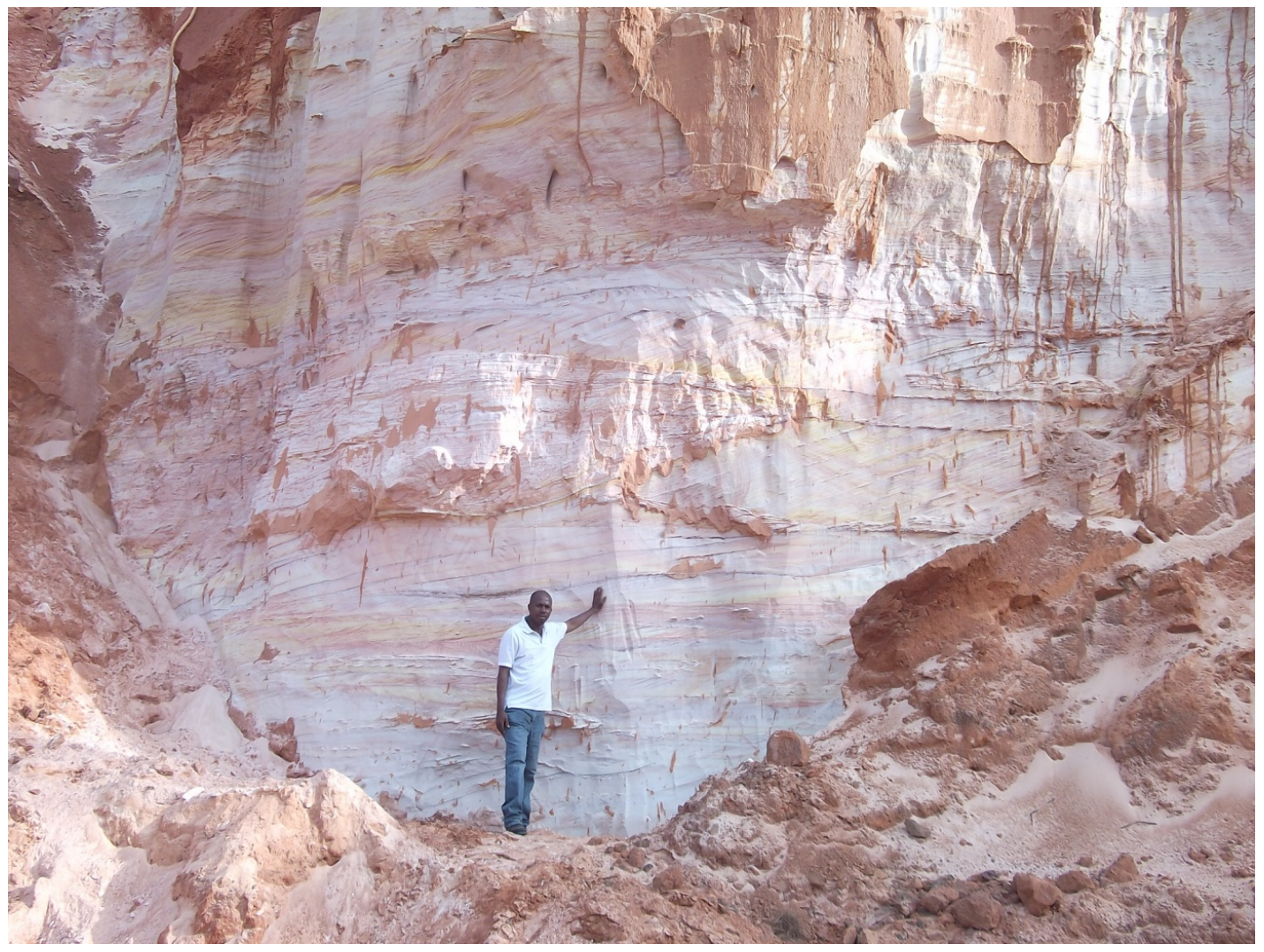

Figure 7. Cross bedded sandstone of the Ajali Sandstone around Dekina (4 km from Odugbo) 


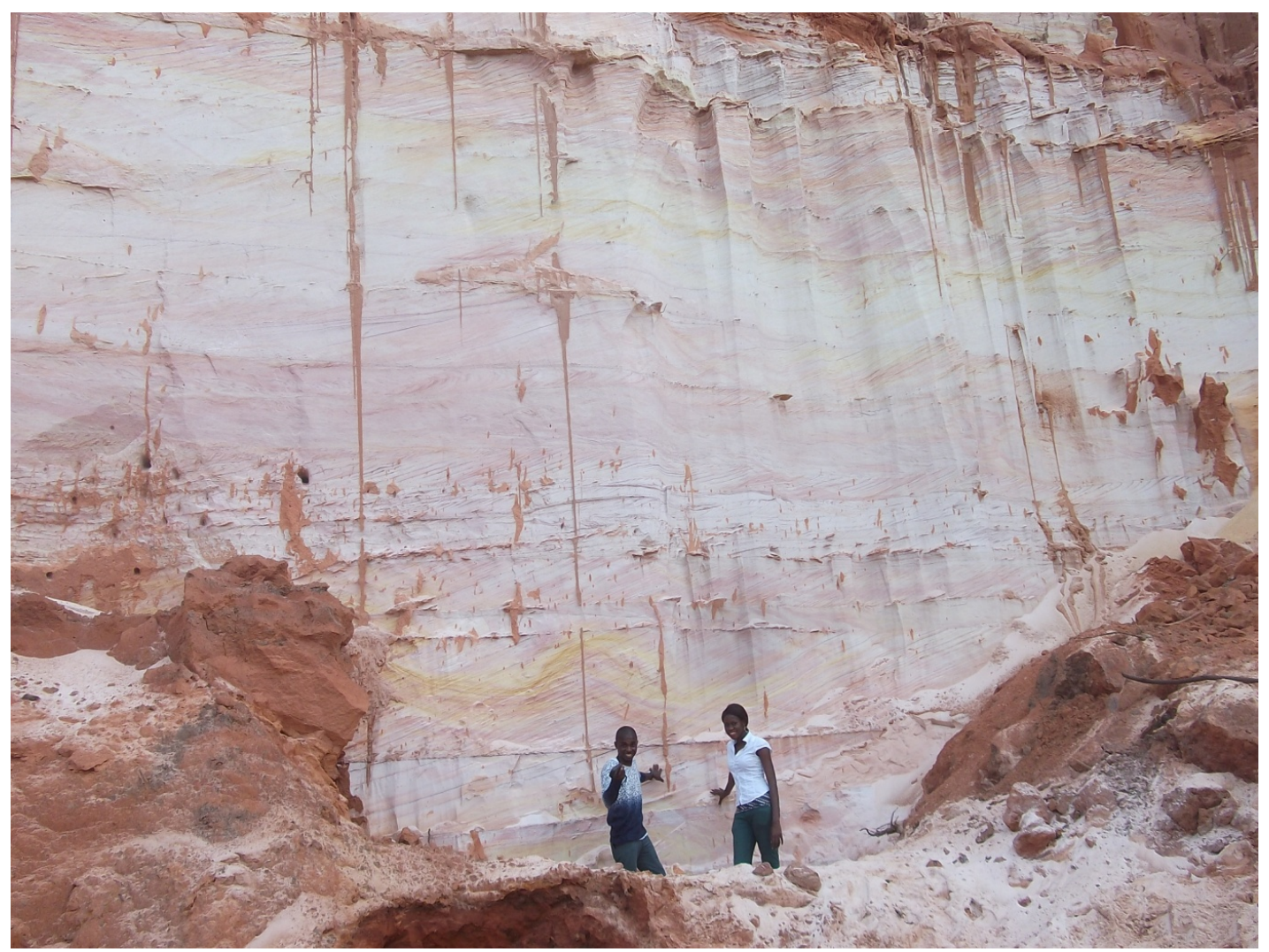

Figure 8. Cross bedded sandstone of the Ajali Sandstone around Dekina (4.5 km from Odugbo)

\subsubsection{Textural Characteristics}

The result of the grain size analysis computed in Table 2 shows that the mean grain size range from 0.98 ф -2.2 $\phi$ indicating fine to coarse grained and moderately to poorly sorted $(0.94 \phi-2.03 \phi)$.

Table 2. Grain size analysis data for the Ajali Sandstone around Odugbo

\begin{tabular}{|c|c|c|c|c|c|}
\hline Samples & $\begin{array}{l}\text { Mean Grain } \\
\text { size }(\phi)\end{array}$ & $\begin{array}{l}\text { Sorting } \\
\text { (SD) ( } \phi)\end{array}$ & $\begin{array}{l}\text { Kurtosis } \\
(\phi)\end{array}$ & Skewness & Interpretation \\
\hline A & 1.40 & 1.03 & 1.74 & 0.34 & $\begin{array}{l}\text { Medium grained, poorly sorted, very } \\
\text { leptokurtic, fine skewed sandstone. }\end{array}$ \\
\hline B & 0.98 & 1.84 & 0.86 & 0.13 & $\begin{array}{l}\text { Medium grain, poorly sorted, platykurtic, } \\
\text { fine skewed sandstone. }\end{array}$ \\
\hline $\mathrm{C}$ & 2.2 & 2.0 & 0.5 & -0.61 & $\begin{array}{l}\text { Fine grained, poorly sorted, platykurtic, } \\
\text { coarse skewed sandstone. }\end{array}$ \\
\hline $\mathrm{D}$ & 1.47 & 0.94 & 2.05 & 0.11 & $\begin{array}{l}\text { Medium grained, moderately sorted, very } \\
\text { leptokurtic, fine skewed sandstone. }\end{array}$ \\
\hline $\mathrm{E}$ & 1.03 & 1.83 & 0.82 & 0.14 & $\begin{array}{l}\text { Coarse grained, poorly sorted, platykurtic, } \\
\text { fine skewed sandstone. }\end{array}$ \\
\hline $\mathrm{F}$ & 2.15 & 2.03 & 0.55 & -0.58 & $\begin{array}{l}\text { Fine grained, poorly sorted, very platykurtic, } \\
\text { strongly skewed sandstone. }\end{array}$ \\
\hline
\end{tabular}




\subsubsection{Reservoir Property}

Sieve data plotted on semi-log sheet was used to determine the $50^{\text {th }}$ percentile or median diameter $\left(\mathrm{d}_{50}\right)$ and sorting. These data were substituted into the empirical formula proposed by Krumbrien and Monk (1942) to estimate permeability (Table 3) of the sandstone. Generally, the sandstones were grouped into two facies as cross bedded and parallel bedded sandstone facies (Table 3).

Table 3. Textural and permeability data of the Ajali Sandstone around Odugbo, North central, Nigeria

\begin{tabular}{|c|c|c|c|c|c|}
\hline Samples / Facies & $\begin{array}{l}\text { Median size } \\
\left(d_{50}\right)\end{array}$ & $\begin{array}{l}\text { Sorting } \\
(\phi)\end{array}$ & $\begin{array}{l}\text { Permeability } \\
\text { (md) }\end{array}$ & $\begin{array}{l}\text { Sandstone } \\
\text { type }\end{array}$ & $\begin{array}{l}\text { Flow characteristics } \\
\text { (After Todd, 1960) }\end{array}$ \\
\hline $\begin{array}{l}\text { A / Cross bedded } \\
\text { sandstone }\end{array}$ & 0.38 & 1.03 & 30.50 & $\begin{array}{l}\text { Quartz } \\
\text { arenite }\end{array}$ & Poor \\
\hline $\begin{array}{l}\text { B / Cross bedded } \\
\text { sandstone }\end{array}$ & 0.54 & 1.84 & 110.03 & $\begin{array}{l}\text { Quartz } \\
\text { arenite }\end{array}$ & Poor \\
\hline $\begin{array}{l}\text { C / Parallel bedded } \\
\text { sandstone }\end{array}$ & 0.11 & 2.0 & 4.96 & $\begin{array}{l}\text { Sub lithic } \\
\text { arenite }\end{array}$ & Poor \\
\hline $\begin{array}{l}\text { D / Cross bedded } \\
\text { sandstone }\end{array}$ & 0.32 & 0.94 & 19.74 & $\begin{array}{l}\text { Quartz } \\
\text { arenite }\end{array}$ & Poor \\
\hline $\begin{array}{l}\text { E / Cross bedded } \\
\text { sandstone }\end{array}$ & 0.54 & 1.83 & 109.43 & $\begin{array}{l}\text { Quartz } \\
\text { arenite }\end{array}$ & Poor \\
\hline $\begin{array}{l}\text { F / Parallel bedded } \\
\text { sandstone }\end{array}$ & 0.12 & 2.03 & 5.99 & $\begin{array}{l}\text { Quartz } \\
\text { arenite }\end{array}$ & Poor \\
\hline
\end{tabular}

\subsubsection{Petrography}

The sandstones are composed of mostly quartz, feldspar and mica. Other components include rock fragments and hematite cement (Figures 9 and 10). The compositions of the minerals include quartz (95.08\%), feldspar (2.55\%) and mica plus rock fragments $(1.19 \%)$.

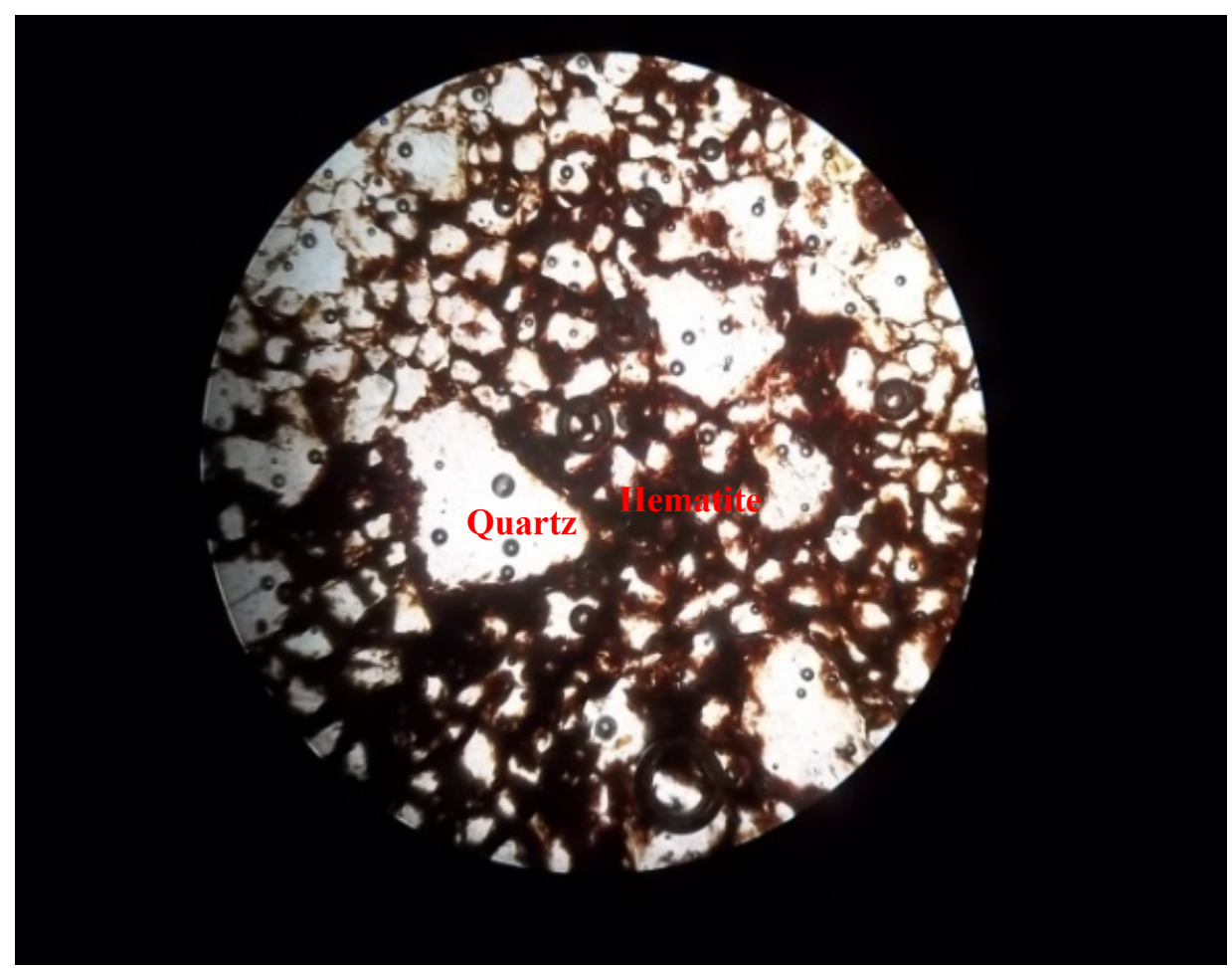

Figure 9. Photomicrograph of Ajali Sandstone containing hematite cement (Plain Polarized) 


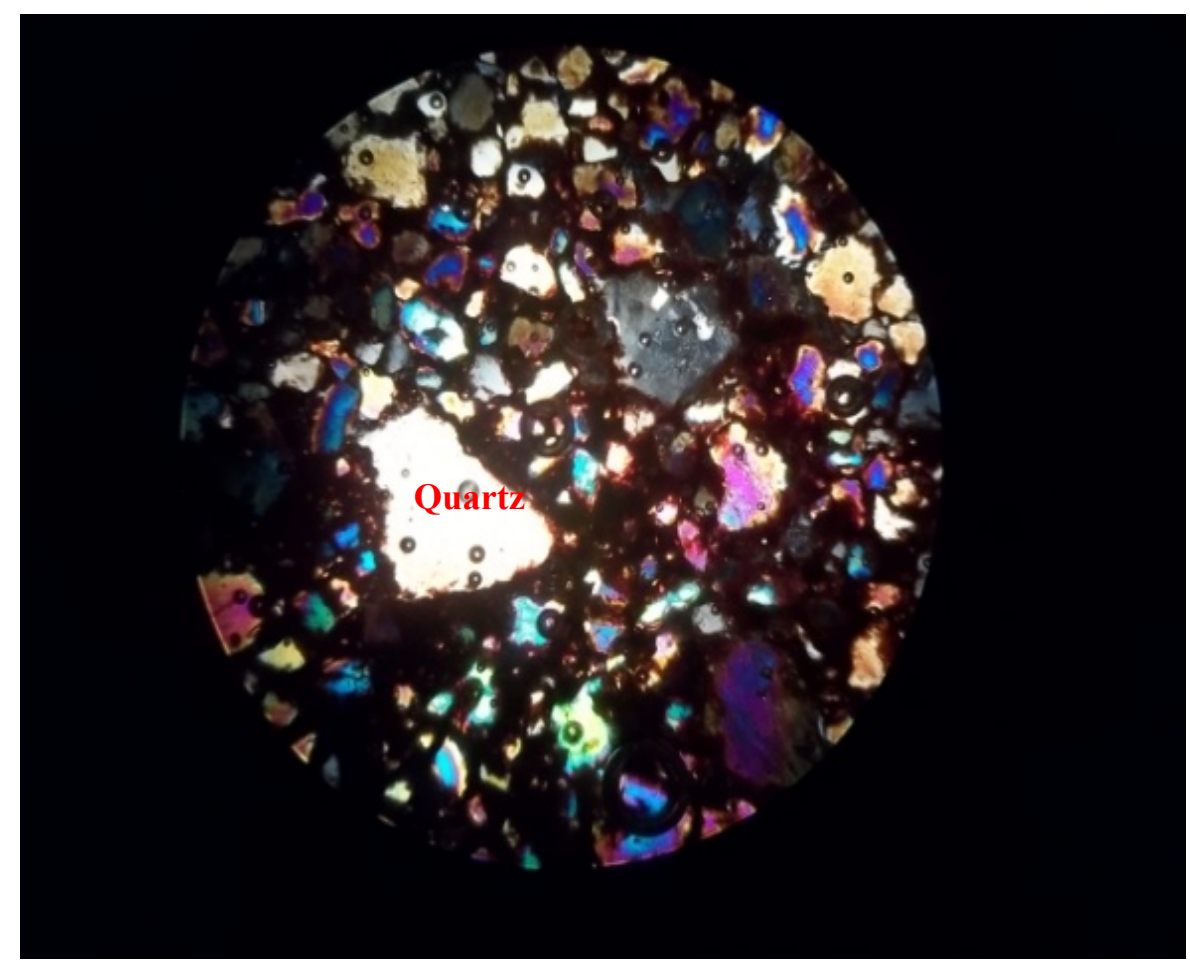

Figure 10. Photomicrograph of Ajali Sandstone containing hematite cement, around Odugbo (Plain Polarized)

This composition in percentage plotted on a ternary diagram (Figure 11) shows that the sandstones are mainly quartz arenite (after Folk, 1974).

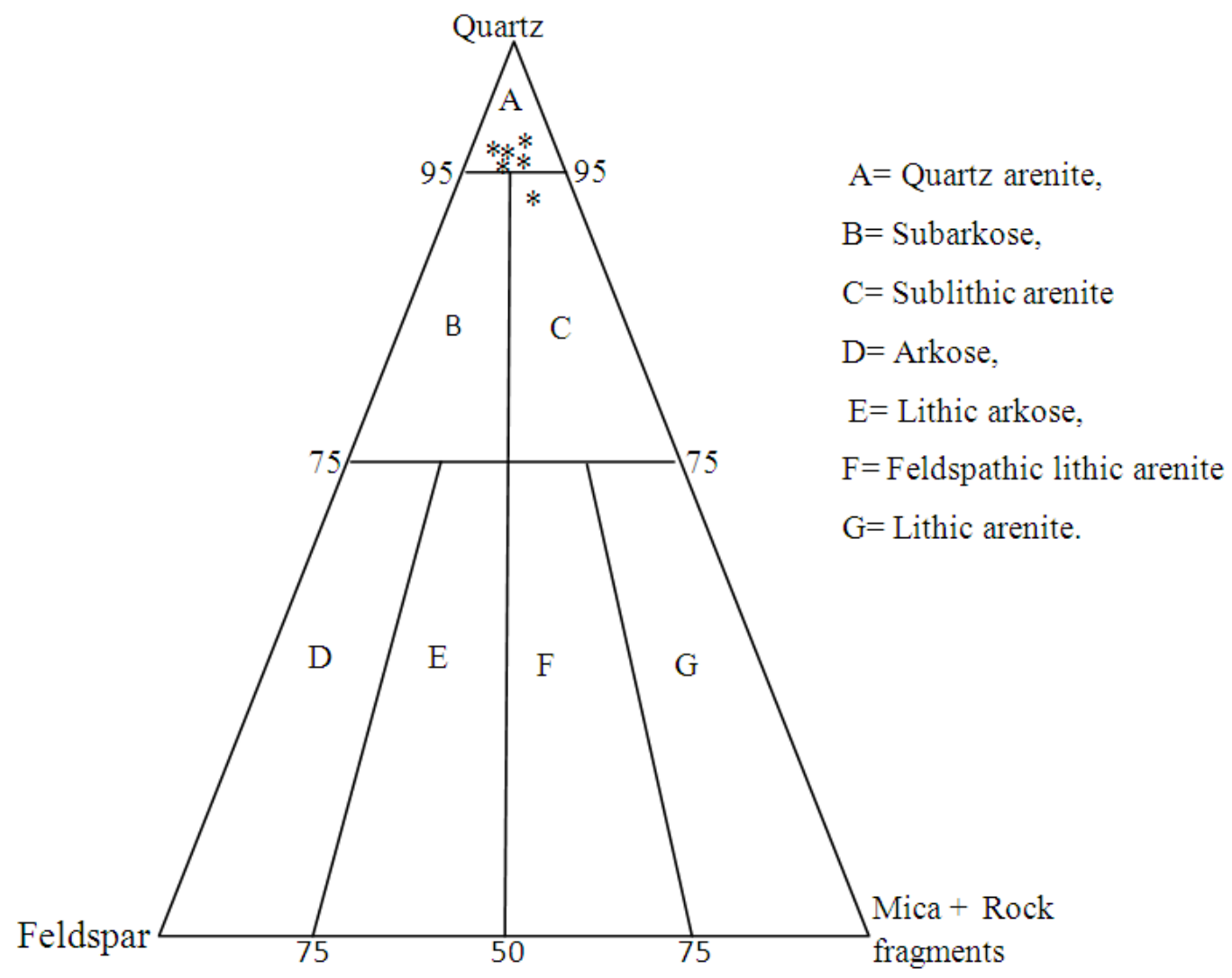

Figure 11. Classification of Sandstone (After Folk, 1974) 


\subsection{Discussion}

Grain size analysis shows that the sandstones are composed of mainly fine to coarse grained particles which suggest changes in physical energy at the time of deposition. The poor sorting of the particles may be an indicator of sediment deposited in fluvio-continental setting (Friedman, 1967). The sandstone is also loosely packed and grain shape range from sub angular to sub-rounded which indicates nearby source of derivation. The high percentage of quartz (95.08\%) and low feldspar (2.55\%) shows that the sandstone are mineralogically matured and derived from quartz-rich rock. Sedimentary structures encountered include parallel bedding, lamination and planar cross bedding. The shale lamination shows deposition in a quiet environment and laminated unit of the sandstone inferred deposition from suspension when the wave energy begin to wane and the sand begin to fall out of suspension (Adediran et al., 1991; Tucker, 1996). The planar cross bedding is a reflection of river deposition by migrating sand waves (Harms et al., 1975). The permeability values derived from the empirical formula are generally very low with an average of 46.76md and were adjudged to have poor flow characteristics (Todd, 1960). This poor flow characteristic may be as a result of the presence of hematite cement probably formed by chemical weathering and grain dissolution. The permeability value of the medium grained sandstone at the bottom section $(2-3$ metres) is lower than that of the medium grained sandstone with planar cross bedding (Figure 5 and 6). This suggests that sedimentary structures and depth of burial may have a significant impact on permeability of the Ajali Sandstone. Also the variations in permeability between the facies (cross bedded and parallel facies) may produce reservoirs with different vertical and lateral architecture in the subsurface outcrops of the basin. Horizontal bounding surfaces (Figure 8) also observed in the cross bedded sandstone however may be the loci of permeability baffles that may affect reservoir behavior in the cross bedded facies while the haematite cement present in the parallel bedded sandstone has strong effect on the petrophysical properties. Moreso, due to the sedimentological differences between the two facies, significant permeability anisotropy arises.

\section{Conclusion}

Ajali Sandstone around Odugbo consists of planar cross bedded quartz arenite and parallel bedded sandstone intercalated with shale. The planar cross bedded and parallel bedded sandstones were medium grained, poorly sorted, fine skewed and very leptokurtic to platykurtic. Consideration of the textural characteristics and sedimentary structures suggest a fluvial dominated regime. The average permeability value of the sandstone is $46.76 \mathrm{md}$ is low. This low permeability (reflecting fair to and poor flow characteristics) may have resulted from weathering and grain dissolution during the formation of hematite cement in the sandstone. This study also shows that sedimentary structures and depth of burial can be considerable factors affecting the permeability of sandstone.

\section{References}

Adediran, S. A., Adegoke, O. S., \& Oshin, I. O. (1991). The continental sediments of the Nigerian Coastal Basins. African Earth Science Journal, 12(1-2), 79-84. http://dx.doi.org/10.1016/0899-5362(91)90059-8

Akande, S. O., Ogunmoyero, I. B., Petersen, H. I., \& Nytoft, H. P. (2007). Source rock evaluation of coals from the Lower Maastrichtian Mamu Formation, SE Nigeria. Petroleum Geology Journal, 30(4), 303-324. http://dx.doi.org/10.1111/j.1747-5457.2007.00303.x

Allix, P. (1987). Le basin de Anambra, essaide caraterisation de l'evolution tectonosedimentare au cretace superieur, Bulletin des Centres Recherches Exploration Production. Elf Aquitaine, 11, 158-159.

Dickson, W. R. (1970). Interpreting detrital modes of Greywacke and Arkose. Sedimentary Petroogy Journal, 40, 695-707.

Folk, R. L., \& Ward, W. (1957). Brazos River Bar. A study in Significance of Grain-size Parameters. Sedmentary Petrology Journal, 27, 3-26. http://dx.doi.org/10.1306/74D70646-2B21-11D7-8648000102C1865D

Folk, R. L. (1974). Petrology of Sedimentary Rocks. Texas: Hemphill Publ. Co. Austin.

Friedman, G. M. (1967). Dynamic Process and Statistical Parameters Compared for size Frequency Distribution of Beach and River Sands. Sedmentary Petrology Journal, 37, 327-354.

Friedman, G. M. (1979). Differences in size distribution of populations among sands of various origins. Sedimentology, 26, 3-32. http://dx.doi.org/10.1111/j.1365-3091.1979.tb00336.x

Harms, J. C., Southard, J. B., Spearing, D. R., \& Walker, R. G. (1975). Stratification Produced by Migrating Bedforms: In Depositional Environment as Interpreted from Primary Sedimentary Structure and Stratification Sequences. S.E.P.M. Short Course. No. 2. 
Hoque, M. (1977). Petrography Differentiation of Tectonically Controlled Cretaceous Sedimentary Cycles, $\begin{array}{llllll}\text { Southeastern Nigeria. Sedmentary Petrology } & \text { Journal, }\end{array}$ http://dx.doi.org/10.1016/0037-0738(77)90047-1

Hoque, M., \& Ezepue, M. C. (1977). Petrology and Paleogeography of the Ajali Sandstone. Mining \& Geology Jornal, 14(1), 16-22.

Ingersoil, R. V., Bullard, T. F., Ford, R. L., Grim, J. P., Pickle, J. D., \& Sares, S. W. (1984). The effects of grain size on data modes : a test of the Gazzi - Dickson point - counting method. Sedmentary Petrology Journal, $46,620-632$.

Kriesa, R. D., Unomah, G. I., Joiner, S. D., Oluwale, Y. R., \& Leininger, S. C., (1999). Improved reservoir description and development through quantitative interpretation of Core data. Nigeria Association of Petroleum Exploration Bulletin, 14, 1-17.

Krumbrien, W. C., \& Monk, G. D. (1942). Permeability as a function of size parameters of unconsolidated sand. Petroleum Technology, 5, 1-11.

Ladipo, K. O. (1986). Tidal Shelf depositional model for the Ajali Sandstone, Anambra basin, southern Nigeria. African Earth Scientist Journal, 5(2), 177-185. http://dx.doi.org/10.1016/0899-5362(86)90008-4

Ladipo, K. O. (1988). Paleogeography, sedimentation and tectonics of the Upper Cretaceous Anambra basin, South eastern Nigeria. African Earth Scientist Journal, 7(5-6), 865-871. http://dx.doi.org/10.1016/0899-5362(88)90029-2

Murat, R. C. (1972). Stratigraphy and Paleogeography of the Cretaceous and Lower Tertiary in the southern Nigeria. In: T. F. J Dessauvagie, \& A. J. Whiteman (Eds), African Geology. Nigeria: University of Ibadan press.

Obi, G. C., Okogbue, C. O., \& Nwajide, C. S. (2001). Evolution of the Enugu Cruesta: A tectonically driven erosional process. Global Journal of Pure \& Applied Science, 7, 321-330.

Odedede, O. (2011). Sedimentology and palaeoenvironment of the Gombe Sandstone and Lower Kerri-Kerri Formation around Biri Fulani, Upper Benue Trough, northeastern Nigeria. Mining \& Geology Journal, $47(1), 1-17$.

Okogbue, C. O., \& Ugwoke, T. S. (2012). Inferring Hydrocarbon Migration and Sealing potentials of Some Shales of the Anambra Basin (South - Eastern Nigeria) from Their Paragenesis and Geotechnical Index

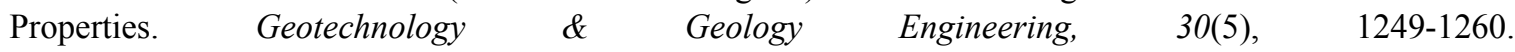
http://dx.doi.org/10.1007/s10706-012-9538-x

Reyment, R. A. (1965). Aspects of Geology of Nigeria. Nigeria: University of Ibadan press.

Simpson, A. (1954). The Nigerian Coal Field: The Geology of parts of Owerri and Benue Provinces. Nigerian Geology Survey Bulletin. No.24.

Todd, D. K. (1960). Groundwater hydrology. New York: Willey.

Tijani, M. N., Nton, M. E., \& Kitagawa, R. (2010). Textural and geochemical characteristics of the Ajali Sandstone, Anambra Basin, SE Nigeria: Implication for its provenance. C. R. Geoscience, 342(2), 136-150. http://dx.doi.org/10.1016/j.crte.2009.09.009

Tucker, M. E. (1996). Sedimentary rocks in the field (2nd ed.). Chichester, John Wiley and Sons.

\section{Copyrights}

Copyright for this article is retained by the author(s), with first publication rights granted to the journal.

This is an open-access article distributed under the terms and conditions of the Creative Commons Attribution license (http://creativecommons.org/licenses/by/3.0/). 